\title{
Giant appendiceal mucocele mimicking an ovarian tumour
}

\author{
Sun Young Lee, ${ }^{1}$ Dong Hyu Cho (1) ${ }^{2}$
}

'Department of Radiation Oncology, Jeonbuk

National University Medical School, Research Institute of Clinical Medicine of Jeonbuk National Uinversity-Biomedical Research Institute, Jeonbuk National University Hospital, Jeonju, Jeollabuk-do, The Republic of Korea

${ }^{2}$ Department of Obstetrics and Gynecology, Jeonbuk National University Medical School, Research Institute of Clinical Medicine of Jeonbuk National Universiy-Biomedical Research Institute, Jeonbuk National University Hospital, Jeonju, The Republic of Korea

Correspondence to Professor Dong Hyu Cho; obgyn2001@jbnu.ac.kr

Accepted 2 May 2021
A) Check for updates

(c) BMJ Publishing Group Limited 2021. No commercial re-use. See rights and permissions. Published by BMJ.

To cite: Lee SY, Cho DH. BMJ Case Rep 2021;14:e243753. doi:10.1136/bcr-2021-

243753

\section{DESCRIPTION}

A 70-year-old multiparous woman was diagnosed with an ovarian tumour at a local obstetrics and gynaecology clinic with abdominal pain that started 2 weeks prior and was transferred to our hospital.

A movable mass as large as the woman's fist was palpated in the right adnexa on pelvic examination. Pelvic ultrasonography showed a $9 \times 5 \times 4 \mathrm{~cm}$ welldefined mixed echogenic mass in the right pelvic cavity. Contrast-enhanced abdominal CT showed a $9 \times 5 \times 4 \mathrm{~cm}$ well-defined solid cystic mass with low signal intensity in the right ovarian fossa (figure 1).

Tumour markers were within normal limits (CA125: $13.1 \mathrm{U} / \mathrm{mL}$ and CA19-9: $10.63 \mathrm{U} / \mathrm{mL}$ ).

Under general anaesthesia, exploratory laparoscopy was performed on suspicion of ovarian tumour. The uterus and both adnexa were normal. The mass was located near the right ovarian fossa, but it was an oval-shaped giant cyst originating from the appendix. Neither enlargement of lymph nodes around the mass nor metastasis was found. We removed the mass carefully through the endobag after complete surgical resection (figure 2). No major intraoperative complications were noted.

Based on gross findings, the appendix showed an oval-shaped cystic expansion filled with thick mucus. Microscopic finding revealed that the appendix was composed of a mucinous cystic lesion with mucin containing a tall columnar cell lining; hence, the patient was diagnosed with a benign mucinous tumour of the appendix (figure 3).

The patient made an uneventful postoperative recovery and was discharged home on the fourth postoperative day.

Appendiceal mucocele is a benign or malignant tumour that arises in the appendix and refers to a condition of expanded appendix with a lumen full of abnormal mucoid substances. ${ }^{12}$
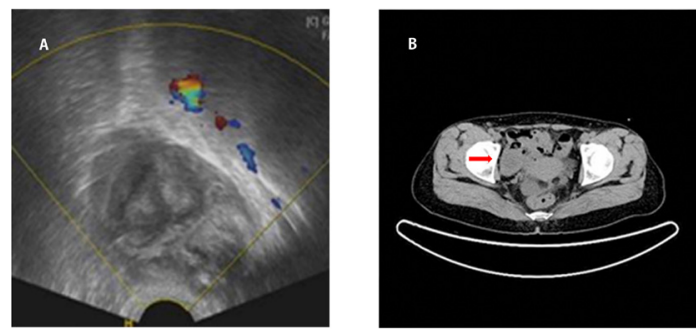

Figure 1 (A) Pelvic ultrasound reveals a well-defined mixed echogenic mass measuring $9 \times 5 \times 4 \mathrm{~cm}$ within the right adnexa. (B) Contrast-enhanced abdominal CT shows a $9 \times 5 \times 4 \mathrm{~cm}$ well-defined solid-cystic mass with low signal intensity within the right adnexa.
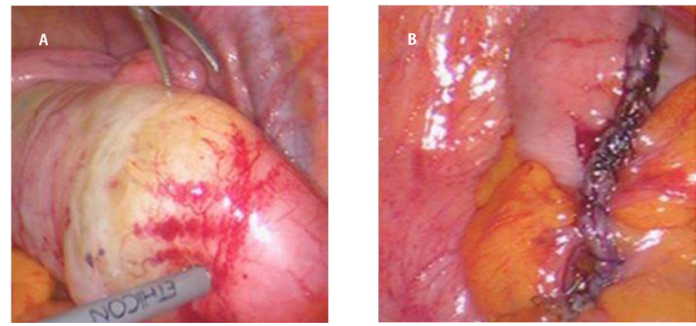

Figure 2 Intraoperative findings. (A) Oval-shaped giant cyst originating from the appendix located near the right ovarian fossa. (B) Complete surgical resection was performed.

The incidence is relatively rare at $0.2 \%-0.3 \%$ in patients who had appendectomy, and cases preoperatively diagnosed in early stage are known to be very rare. ${ }^{3}$

Appendicel mucocele may mimic other adnexal lesions such as tubo-ovarian abscess, hydrosalpinx and ovarian mucinous tumour. ${ }^{45}$

Approximately 25\% of cases of mucocele of the appendix are symptomless and identified by chance.

Most cases are found during examinations due to lower abdominal pain.

Delayed diagnosis due to the abovementioned reasons or intraperitoneal rupture due to careless practice during surgery may result in complications, including pseudomyxoma peritoneum.

Appendiceal mucocele yields a favourable prognosis in cases without complications, such as

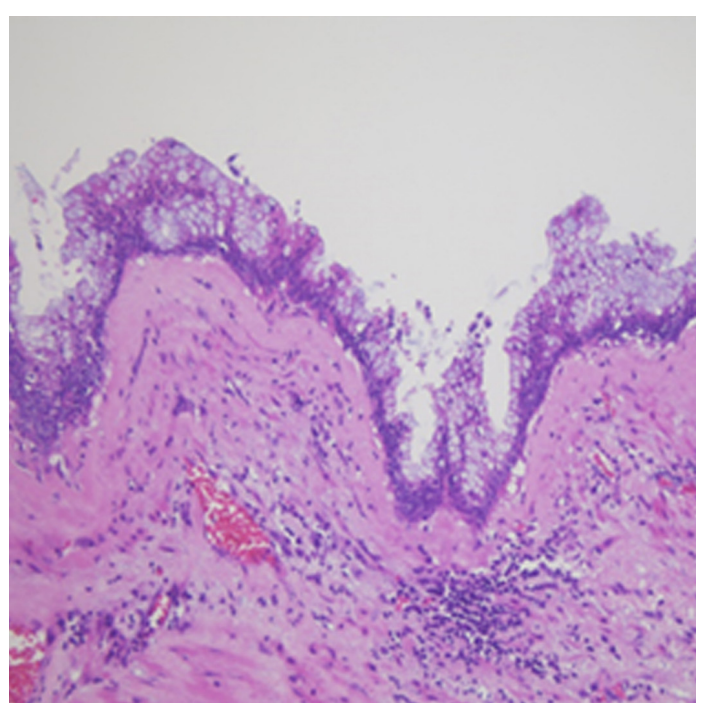

Figure 3 Histologic features of the appendix. The appendix shows a mucinous cystic lesion with mucin containing tall columnar cell lining (H\&E,200x). 
pseudomyxoma peritonei. In addition, it is rarely malignant, and a differential diagnosis is important given that it appears in the form of an intra-abdominal mass or submucosal tumours in the cecum.

\section{Learning points}

- Appendicel mucocele is benign or malignant tumour that arises in the appendix.

- Approximately $25 \%$ of mucocele of the appendix are symptomless and are found by chance and most cases are found during examinations due to lower abdominal pain.

- Rupture during the surgery may cause pseudomyxoma peritoneum, and background knowledge on such case is required and careful removal is essential.

Contributors All persons who meet authorship criteria are listed as authors, and all authors certify that they have participated sufficiently in the work to take public responsibility for the content, including participation in the concept, design, analysis, writing or revision of the manuscript. Furthermore, each author certifies that this material or similar material has not been and will not be submitted to or published in any other publication before its appearance in the BMJ case reports. Authorship contributions: Category 1: Conception and design of study: SYL and DHC. Acquisition of data: SYL and DHC. Analysis and/or interpretation of data: SYL and DHC. Category
2: Drafting the manuscript: SYL and DHC. Revising the manuscript critically for important intellectual content: SYL and DHC.

Funding The authors have not declared a specific grant for this research from any funding agency in the public, commercial or not-for-profit sectors.

Disclaimer Case reports provide a valuable learning resource for the scientific community and can indicate areas of interest for future research. They should not be used in isolation to guide treatment choices or public health policy.

Competing interests None declared.

Patient consent for publication Obtained.

Provenance and peer review Not commissioned; externally peer reviewed.

\section{ORCID iD}

Dong Hyu Cho http://orcid.org/0000-0002-1557-9575

\section{REFERENCES}

1 Stocchi L, Wolff BG, Larson DR, et al. Surgical treatment of appendiceal mucocele. Arch Surg 2003:138:585-90.

2 Tirumani SH, Fraser-Hill M, Auer R, et al. Mucinous neoplasms of the appendix: a current comprehensive clinicopathologic and imaging review. Cancer Imaging 2013;13:14-25

3 B B SK, Jasuja P. Appendiceal mucocele-A rare case report. Int I Surg Case Rep 2019:58:21-5.

4 Hajrunisa C, Vesna C, Nina B. Mucocele of the appendix presenting as an exacerbated chronic tubo-ovarian abscess. Medicine 2019;98:e17149.

5 Borges AL, Reis-de-Carvalho C, Chorão M, et al. Low-Grade mucinous appendiceal neoplasm mimicking an ovarian lesion: a case report and review of literature. World J Clin Cases 2021;9:2334-43.

Copyright 2021 BMJ Publishing Group. All rights reserved. For permission to reuse any of this content visit

https://www.bmj.com/company/products-services/rights-and-licensing/permissions/

BMJ Case Report Fellows may re-use this article for personal use and teaching without any further permission.

Become a Fellow of BMJ Case Reports today and you can:

- Submit as many cases as you like

- Enjoy fast sympathetic peer review and rapid publication of accepted articles

- Access all the published articles

- Re-use any of the published material for personal use and teaching without further permission

\section{Customer Service}

If you have any further queries about your subscription, please contact our customer services team on +44 (0) 2071111105 or via email at support@bmj.com.

Visit casereports.bmj.com for more articles like this and to become a Fellow 